\title{
Hopes for Japanese funds fade
}

\section{Tokyo}

THE sudden decision last week by US President George Bush not to visit Japan at the end of this month may kill all hope of a Japanese financial contribution to the Superconducting Super Collider (SSC) project, Japanese government officials say.

Bush was due to meet Japan's new prime minister Kiichi Miyazawa at the end of this month, but he called off the summit and a trip to other parts of Asia, partly in response to criticism in the United States that he has not been giving enough attention to domestic problems.

One of the principal issues to be discussed by Bush and Miyazawa in Tokyo was to have been the SSC. Last month, Japanese government officials told their US counterparts that none of the sciencerelated ministries or agencies of the Japanese government can provide the $\$ 1,000$ million or so that the United States is seeking from Japan to support construction of the SSC (see Nature 353, 685; 24 October 1991). The only hope left is that Japan's prime minister may make a political decision to support the project in much the same way as former Prime Minister Toshiki Kaifu agreed to put more than $\$ 9,000$ million dollars into the Gulf War.

The November meeting with Bush was ripe for such a decision. Miyazawa, having just taken office, would have been looking for a way to start off on friendly terms with the US president. Also, under Japanese tradition, it would have been important for Miyazawa to give Bush some nice 'souvenir' to take home after their first meeting as leaders of their two countries. The only obvious thing was a contribution to the SSC, say government officials familiar with the planned meeting.

Furthermore, the timing was right. The Japanese budget for next fiscal year will

\section{Cold fusion leaves a legacy}

\section{Tokyo}

THE fuss over cold fusion in 1989 may not have advanced the frontiers of science very much, but it did help to launch a major collaborative effort between UK and Japanese scientists, according to the Japanese leader of the project. The world's most powerful pulsed muon source, on which construction is scheduled to begin early next year, received funding partly because of the early cold fusion claims.

Scientists from the Rutherford Appleton Laboratory in the United Kingdom last week visited the Institute of Physical and Chemical Research (RIKEN) in Wako city near Tokyo to finalize details of plans to build the muon source at the British laboratory with funds from Japan's Science and Technology Agency. The $¥ 3,000$-million ( $\$ 23$-million) project is one of the first substantial contributions by the Japanese government to British science.

The joint project was first discussed by Japanese and British scientists in late 1988 and it began to move forward a few months later with the support of the British Council in Tokyo. But the key factor that translated an idea into reality was cold fusion, says Kanetada Nagamine of RIKEN, who leads the Japanese side of the project.

In late March 1989, after Stanley Pons and Martin Fleischmann announced their claims of cold fusion, Nagamine was summoned by the science committee of Japan's ruling Liberal Democratic Party to explain what all the fuss was about. His presentation made an impression. Although an earlier request to the Ministry of Education, Science and Culture had been rejected a few weeks earlier, Nagamine's budget request to the Science and Technology Agency - which had been submitted rather late - began to progress rapidly after the meeting with the committee, and the request to the agency was accepted in July.

Nagamine says this is a "world record" by Japanese standards, because in Japan it normally takes years of "root digging" (nemawashi) to launch a project of this size. "It's the only good thing to have come out of cold fusion," he says.

Rutherford Appleton Laboratory was chosen because it has the world's most powerful pulsed proton source, which will be used to make the pulsed muon beam. Construction of the facility will begin in January and the first experiments with the muon beam are expected to begin in 1993 or 1994, according to W.G. Williams, head of the muon group at the British laboratory. The facility, which is funded completely by Japan, will be built by British industry, although the superconducting magnets will come from Japan.

The beam will produce both negatively charged and positively charged high-energy muons. The negatively charged muons, which behave like heavy electrons and are attracted to the positive nuclei of atoms, will be used to investigate muon-catalysed fusion as well as for nondestructive element analysis and for material synthesis through element conversion. The positive muons, which are repelled by nuclei, will be used to characterize materials such as high-temperature superconductors.

David Swinbanks be finalized at the end of December and Miyazawa could have slipped in an extra provision for the SSC.

The opportunity has been lost with Bush's decision to postpone the meeting. Senior officials from the US Department of Energy will still visit Japan at the end of this month to try to win SSC funds, but an official of Japan's Science and Technology Agency says they do not stand a chance. He says he has repeatedly told US embassy officials in Tokyo that the only hope lies in a Bush-Miyazawa meeting. And, now that that has been postponed, no decision can be made by Japan for at least another year until the next round of Japanese budget decisions, by which time the political climate may have changed completely.

David Swinbanks

\section{FRENCH BLOOD SCANDAL}

\section{The clot thickens}

\section{London}

THE controversy surrounding the French blood transfusion service deepened last week with the announcement that another former official has been charged with knowingly supplying infected blood-clotting factors to French haemophiliacs during 1985. The latest focus of the French prosecutors' attention is Jean-Pierre Allain, who in 1985 was head of blood plasma derivatives research at the French national blood transfusion centre (CNTS).

Michel Garretta, former director of CNTS, already faces an identical charge; two other French health officials of the day, Jacques Roux and Robert Netter, are charged with failing to prevent the distribution of the infected clotting factors (see Nature 353, 781; 31 October 1991). Central to the charges is the accusation that in 1985 the French health ministry and transfusion service, in order to save money and avoid destroying existing stocks of blood products, allowed the distribution of infected clotting factors instead of swiftly introducing safe, heat-treated supplies.

Allain, who is now a lecturer at the University of Cambridge, protests his innocence: "I spent two years fighting" with Garretta over the need to introduce heattreated blood products, he says. (In 1985, Allain estimated that 30 to 60 haemophiliacs could become infected with human immunodeficiency virus (HIV) each month, unless the distribution of potentially contaminated clotting factors was stopped.)

Meanwhile, the infighting among former French officials implicated in the scandal becomes more bitter. Roux now faces a libel suit from former French prime minister Laurent Fabius, after alleging that in 1985 Fabius reduced funds for programmes to screen blood for HIV, contributing to the haemophiliacs' plight.

Peter Aldhous 